\title{
NITROGEN OXIDES, REGIONAL TRANSPORT, AND OZONE AIR QUALITY: RESULTS OF A REGIONAL-SCALE MODEL FOR THE MIDWESTERN UNITED STATES
}

\author{
SANFORD SILLMAN and PERRY J. SAMSON \\ Department of Atmospheric, Oceanic and Space Sciences, University of Michigan, Ann Arbor, \\ MI 48109-2143, U.S.A.
}

(Received October 24, 1990; revised January 29, 1991)

\begin{abstract}
An overview of the role of $\mathrm{NO}_{x}$ in the formation of rural $\mathrm{O}_{3}$, regional transport and its potential impact on urban air quality is presented. An analysis of a specific $\mathrm{O}_{3}$ excursion in southeast Michigan (8-2-90) is performed based on a combined urban and regional-scale model. The regional component of the model represents transport and photochemistry from sources as far away as Texas. Results suggest that rural $\mathrm{O}_{3}$ and regional transport sensitive to $\mathrm{NO}_{x}$ emissions and relatively insensitive to changes in volatile organic carbon (VOC) emissions. This differs from the situation in urban areas, where $\mathrm{O}_{3}$ is sensitive to both $\mathrm{NO}_{x}$ and VOC. Regional transport and upwind $\mathrm{NO}_{x}$ emissions have a significant impact on peak $\mathrm{O}_{3}$ in Detroit. Implications for urban and regional-scale abatement strategies are discussed.
\end{abstract}

\section{Introduction}

It has been apparent for many years that elevated $\mathrm{O}_{3}$ in eastern North America is a regional-scale problem with dimensions that transcend state and even national boundaries. As illustrated in Figure 1, elevated $\mathrm{O}_{3}$ concentrations in eastern North America have been observed to extend over distances of $1500 \mathrm{~km}$ or more and to affect rural air masses as well as urban air [1-4]. Despite the regional nature of the problem, strategies for $\mathrm{O}_{3}$ abatement in the U. S. have been based on models (e.g. EKMA and UAM) which represent a single metropolitan area without explicit regard for the influence of changing upwind emissions. The limited scope of existing air quality models coupled with the failure of past efforts to control $\mathrm{O}_{3}$ [5] suggest the need for a more extensive analysis that includes the impact of regional transport.

This paper presents overview of the factors that affect large-scale regional transport of $\mathrm{O}_{3}$ in eastern North America, and presents a regional-scale analysis of a specific $\mathrm{O}_{3}$ episode in the midwestern U.S. The overview is designed to acquaint readers familiar with the dynamics of $\mathrm{O}_{3}$, nitrogen oxides $\left(\mathrm{NO}+\mathrm{NO}_{2}\right.$, abbreviated as $\mathrm{NO}_{x}$ ) and volatile organic carbon (VOC) in urban locations with the dynamics that affect rural $\mathrm{O}_{3}$ and regional transport. It will be argued that the relation between precursor emissions $\left(\mathrm{NO}_{x}\right.$ and VOC) and regional transport of $\mathrm{O}_{3}$ is fundamentally different from the relation between $\mathrm{O}_{3}$ and precursors in urban centers. Consequently a regional $\mathrm{O}_{3}$ control strategy must involve more than just a sum of localized urban strategies. The analysis of a midwestern $\mathrm{O}_{3}$ episode is based on the Plumes Model, developed at Harvard University for the investigation of regional and global scale 
$\mathrm{O}_{3}$ production, in combination with a nested urban grid model for the Detroit area. The selected episode occurred on August 2, 1988, and is being used by the Michigan Department of Natural Resources (DNR) as the design day for evaluation of abatement strategies in southeast Michigan. Results of the regional-scale model will illustrate the difference between urban and regional control regimes and the potential impact of regional transport on urban air quality.

\section{Background Rural Ozone}

The impact of regional transport on urban air quality can best be understood through the concept of 'background rural ozone'. Background rural $\mathrm{O}_{3}$ refers to the average concentration of $\mathrm{O}_{3}$ over a rural air mass with spatial extent of $450 \mathrm{~km}$ or more. The distinguishing factor in background rural $\mathrm{O}_{3}$ is that it is not associated with export from a specific urban source region (as would occur, for example, in rural Connecticut or Long Island under the influence of the urban plume from New York City). Background $\mathrm{O}_{3}$ represents a uniform concentration over a wide area, and consequently has a high likelihood of being found upwind of major urban centers. Consequently background $\mathrm{O}_{3}$ frequently has an impact on urban air quality as transport of background $\mathrm{O}_{3}$ into the urban center adds to local photochemical production.

The importance of background rural $\mathrm{O}_{3}$ is demonstrated by observations (e.g. Figure 1) which show $\mathrm{O}_{3}$ concentrations in the 0.08 to $0.10 \mathrm{ppm}$ (part per million)

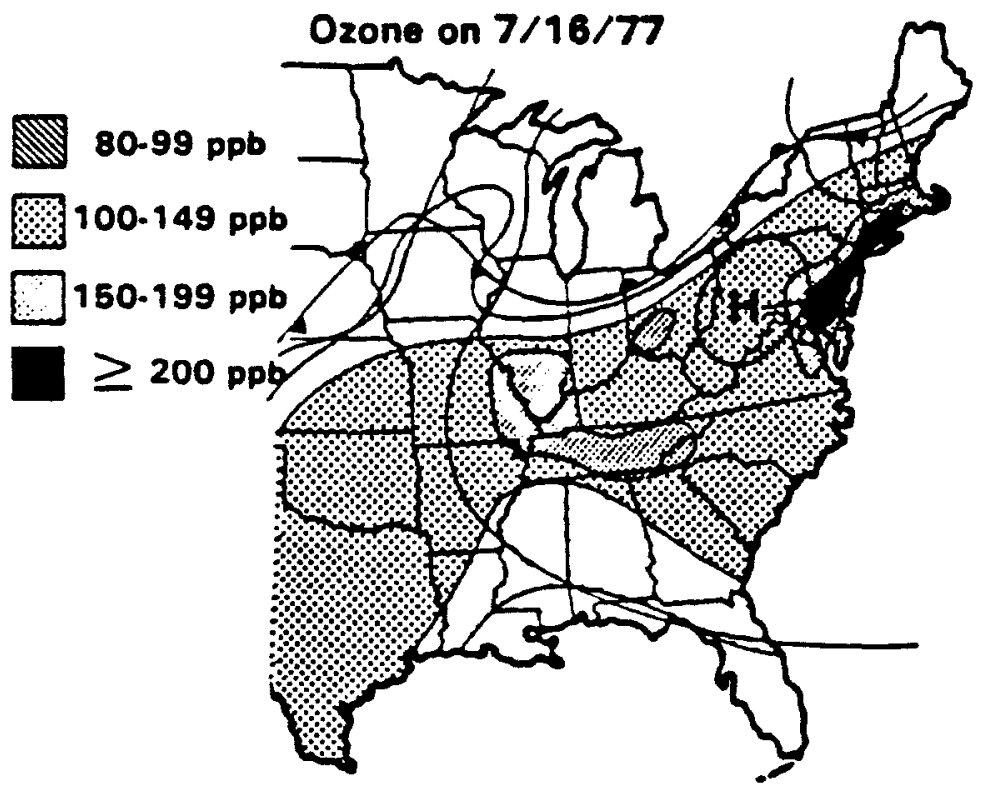

Fig. 1. Observed $\mathrm{O}_{3}$ concentrations at sites in eastern North America on July 16, 1977, from Wolff and Lioy [3]. 
range at rural sites extending over a wide area [3], and by high spatial correlation for $\mathrm{O}_{3}$ concentration at widely separated rural sites [4]. Direct evidence for the extent of high background $\mathrm{O}_{3}$ was provided by an aircraft study by Clarke and Ching [6], in which $\mathrm{O}_{3}$ concentrations were measured along airplane transects through an eastward-moving air mass in Ohio, Pennsylvania and New York. The final transect extended along a $\sim 450 \mathrm{~km}$ path from Fredrick, $\mathrm{MD}$, to Kingston, NY. $\mathrm{O}_{3}$ concentrations ranged from 0.07 to $0.11 \mathrm{ppm}$ along this transect, with an average concentration of $0.09 \mathrm{ppm}$. Observed wind fields made it likely that this air would be transported into the New York, Philadelphia and Washington D.C. metropolitan areas.

Observations $[3,4,6]$ suggest that background $\mathrm{O}_{3}$ in eastern North America frequently reaches 0.08 to $0.10 \mathrm{ppm}$, but rarely exceeds $0.12 \mathrm{ppm}$, the level on which the National Ambient Air Quality Standard (NAAQS) for $\mathrm{O}_{3}$ is based.* However there is a strong likelihood that transport of $\mathrm{O}_{3}$ at concentrations of $0.08-0.10 \mathrm{ppm}$ can contribute to NAAQS violations in downwind urban areas. Observations in southeast Michigan (Figure 2) show a strong correlation between observed peak $\mathrm{O}_{3}$ in the Detroit-Port Huron corridor and peak $\mathrm{O}_{3}$ at Saline, a rural site to the southwest. Exceedences of the NAAQS standard in Detroit are most commonly associated with peak $\mathrm{O}_{3}>0.09 \mathrm{ppm}$ at Saline.

Samson and Shi [7] have identified meteorological circulation (in term of 24hour back-trajectories) associated with elevated $\mathrm{O}_{3}$ in cites throughout the eastern United States. Results for Boston, MA (Figure 3) show that elevated $\mathrm{O}_{3}$ is associated with transport from the North American continent, but not with transport from individual urban centers. Air quality violations in Boston are as likely associated with transport from upstate New York and Ontario as with transport from the northeast corridor. Air quality violations in Boston were never observed when winds were southerly off the ocean. These results suggest that background rural $\mathrm{O}_{3}$, rather than transported urban plumes, has a significant impact on air quality in Boston. Similar results were obtained for other American cities, although interurban transport was also detected in some northeast corridor cities.

\section{Relation between background $\mathrm{O}_{3}$ and Nitrogen Oxides}

The relation between $\mathrm{O}_{3}$ and precursors in urban areas has been the subject of numerous studies and is familiar to air quality analysts [8]. Urban $\mathrm{O}_{3}$ may be sensitive to either $\left(\mathrm{NO}_{x}\right.$ or anthropogenic VOC emission, and sensitivity may vary for different cities, $[9,10]$ or for different locations within the same city [11]. While the processes that contribute to background rural $\mathrm{O}_{3}$ have many similarities to the urban case, there are some fundamental differences between the urban and rural cases. Background rural $\mathrm{O}_{3}$ is most likely sensitive to $\mathrm{NO}_{x}$ emissions and

\footnotetext{
* The NAAQS for $\mathrm{O}_{3}$ is $0.12 \mathrm{ppm}$ hourly average not to be exceeded in any more than three days in any three year period.
} 


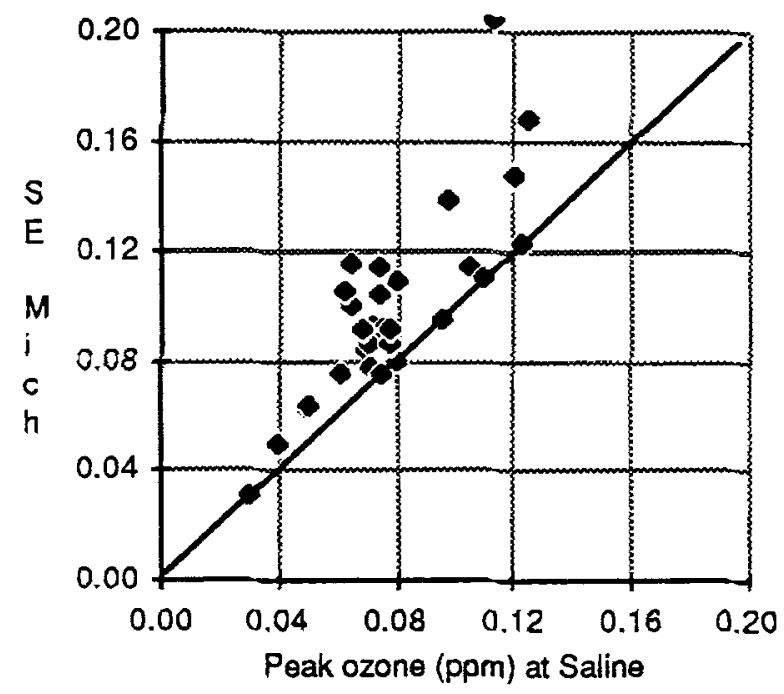

Fig. 2. Diurnal peak hourly $\mathrm{O}_{3}(\mathrm{ppm})$ over ten sites in the Detroit-Port Huron corridor versus diurnal peak hourly $\mathrm{O}_{3}$ observed at Saline, Michigan for July 1-31, 1988. The solid line represents equal xand $y$-axis values.

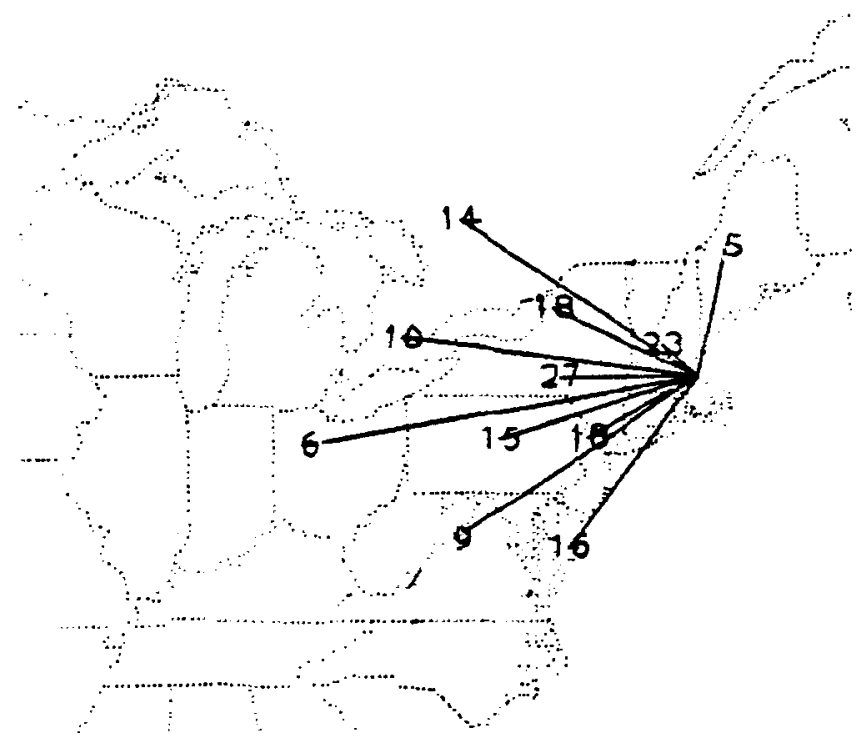

Fig. 3. Mean 24 hr trajectory displacement for wind flow categories associated with $\mathrm{O}_{3}$ concentrations greater than $0.08 \mathrm{ppm}$ for Boston, MA. Numbers refer to the number of events associated with each trajectory displacement category, based on a total of 168 cases during the period 1983-1985. Violations of the 0.12 ppm NAAQS standard were associated with each category roughly in proportion to the number of $>0.08$ ppm events. From Samson and Shi [7]. 
insensitive to $\operatorname{VOC}[12,13]$. Reasons for $\mathrm{NO}_{x}$ dependence of rural $\mathrm{O}_{3}$ relate to photochemical processes and are worth summarizing.

Two major factors contribute to background rural $\mathrm{O}_{3}$ in eastern North America: export of $\mathrm{O}_{3}$ photochemically produced in urban and power plant plumes, and rural photochemical production of $\mathrm{O}_{3}$. The latter is associated with a combination of transport of $\mathrm{O}_{3}$ precursors $\left(\mathrm{NO}_{x}\right.$ and VOC) from urban centers and with precursor emissions from 'distributed' sources, small cities and towns scattered throughout the region. Biogenic VOC emissions also contribute significantly to rural $\mathrm{O}_{3}$ production [12]. Recent calculations suggest that significant $\mathrm{O}_{3}$ production can occur with $\mathrm{NO}_{x}$ concentrations as low as $1 \mathrm{ppb}$ [13]. Observations suggest that daytime $\mathrm{NO}_{x}$ concentrations of $1 \mathrm{ppb}$ are commonly found at rural sites throughout eastern North America $[12,14]$.

Photochemical production of $\mathrm{O}_{3}$ may occur either in a VOC-sensitive photochemical regime or in a $\mathrm{NO}_{x}$-sensitive regime. For urban conditions the divide between VOC-sensitive and $\mathrm{NO}_{x}$-sensitive regimes depends on the relative amounts of $\mathrm{VOC}$ and $\mathrm{NO}_{x}$, with the $\mathrm{VOC}$-sensitive regime occurring when $\mathrm{VOC} / \mathrm{NO}_{x}$ ratios are relatively low and the $\mathrm{NO}_{x}$-sensitive regime occurring when $\mathrm{VOC} / \mathrm{NO}_{x}$ ratios are high. For $\mathrm{NO}_{x}$ concentrations typical of rural areas, photochemistry is likely to be in the $\mathrm{NO}_{x}$-sensitive regime even at low VOC/NO $\mathrm{N}_{x}$ ratios. This is illustrated in Figure 4 (from Sillman et al. [13] which shows calculated $\mathrm{O}_{3}$ versus noon $\mathrm{NO}_{x}$

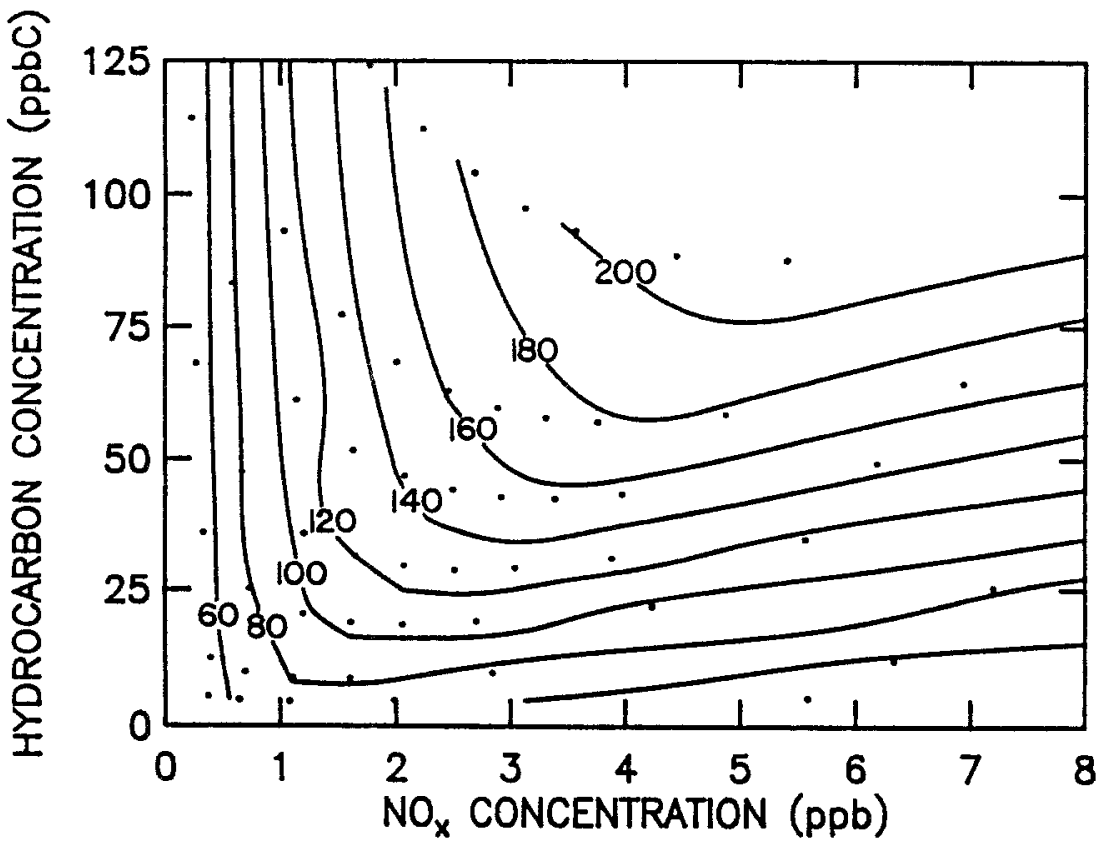

Fig. 4. $\mathrm{O}_{3}$ (in ppb) as a function of the concentrations of $\mathrm{NO}_{x}$ and $\mathrm{VOC}$ (in ppbC) at 4 p.m., based on a calculations representing photochemical evolution during a 4-day stagnation with continuous $\mathrm{NO}_{x}$ and VOC emissions. Dots represent VOC and $\mathrm{NO}_{x}$ concentrations for individual simulations used to derive the $\mathrm{O}_{3}$ contours. Biogenic emissions are zero. From Sillman et al. [13]. 
and VOC concentrations following a 4-day stagnation. Photochemistry is in a $\mathrm{NO}_{x^{-}}$ sensitive regime for $\mathrm{NO}_{x}$ concentrations of $1 \mathrm{ppb}$ or lower, regardless of VOC. The calculation assumes zero biogenic emissions; inclusion of isoprene would extend the $\mathrm{NO}_{x}$ sensitive regime further. For daytime $\mathrm{NO}_{x}$ and VOC concentrations observed in rural Pennsylvania ( $1 \mathrm{ppb} \mathrm{NO}_{x}, 20$ ppbC VOC [13]) the calculated $\mathrm{O}_{3}$ is 0.09 ppm $\left(0.095 \mathrm{ppm}\right.$ if biogenics are included), close to the observed background $\mathrm{O}_{3}$ during region-wide stagnation events.

The existence of a $\mathrm{NO}_{x}$-sensitive photochemical regime at low $\mathrm{NO}_{x}$ concentrations is associated with processes that govern the concentration of $\mathrm{OH}$ and odd hydrogen radicals [13]. Odd hydrogen (defined here as the sum of $\mathrm{OH}, \mathrm{OH}_{2}$ and $\mathrm{RO}_{2}$ radicals such as $\mathrm{CH}_{3} \mathrm{O}_{2}, \mathrm{C}_{2} \mathrm{H}_{5} \mathrm{O}_{2}$, etc,) is removed from the system by one of three processes: formation of peroxides, formation of $\mathrm{HNO}_{3}$, or formation of peroxyacetylnitrate (PAN). When formation of peroxides is the dominant sink for odd hydrogen, the concentration of $\mathrm{HO}_{2}$ is relatively invariant and the rate of $\mathrm{O}_{3}$ production is limited by the reaction

$$
\mathrm{HO}_{2}+\mathrm{NO} \rightarrow \mathrm{OH}+\mathrm{NO}_{2}
$$

followed by photolysis of $\mathrm{NO}_{2}$ to produce $\mathrm{O}_{3}$. The rate of this reaction increases as NO increases, corresponding to the $\mathrm{NO}_{x}$-sensitive photochemical regime. When $\mathrm{HNO}_{3}$ formation is the dominant sink, then the concentration of both $\mathrm{OH}$ and $\mathrm{HO}_{2}$ decrease with increasing $\mathrm{NO}_{x}$, causing $\mathrm{O}_{3}$ formation to slow. The rate-limiting step for $\mathrm{O}_{3}$ formation is now

$$
\mathrm{VOC}+\mathrm{OH} \rightarrow \mathrm{RO}_{2}
$$

or

$$
\mathrm{CO}+\mathrm{OH} \rightarrow \mathrm{HO}_{2}+\mathrm{CO}_{2}\left(\text { with } \mathrm{O}_{2}\right)
$$

and the rate of $\mathrm{O}_{3}$ formation increases with increasing VOC concentration and decrease with increasing $\mathrm{NO}_{x}$. This is the VOC-limited regime. For urban conditions the important reactions are all VOC reactions; inorganic reactions (such as R3 and the formation of $\mathrm{H}_{2} \mathrm{O}_{2}$ ) are relatively minor. Since the rate of peroxide formation increases with $\mathrm{VOC}$ and $\mathrm{HNO}_{3}$ formation increases with $\mathrm{NO}_{x}$, the $\mathrm{NO}_{x}$-sensitive and VOC-sensitive photochemical regimes correspond to high and low VOC/NO ratios respectively. But at low $\mathrm{NO}_{x}$ the inorganic reactions have a major impact and formation of $\mathrm{H}_{2} \mathrm{O}_{2}$ becomes the dominant sink for odd hydrogen. For these conditions the system will be in a $\mathrm{NO}_{x}$-sensitive regimes regardless of the VOC concentration.

The relation between rural $\mathrm{O}_{3}$ and $\mathrm{NO}_{x}$ emissions can be identified in theory based on photochemical mechanisms. Empirical evidence linking rural $\mathrm{O}_{3}$ with $\mathrm{NO}_{x}$ is more difficult to obtain since $\mathrm{NO}_{x}$ and $\mathrm{O}_{3}$ have very different lifetimes within the atmospheric boundary layer $\left(\sim 3\right.$-day lifetime for $\mathrm{O}_{3}, \sim 3$-hr lifetime for $\left.\mathrm{NO}_{x}\right)$. Some empirical evidence may be derived by examining correlations between $\mathrm{O}_{3}$ and $\mathrm{NO}_{y}$, defined as the sum of $\mathrm{NO}_{x}$ and its chemical by-products (PAN, $\mathrm{HNO}_{3}$, 


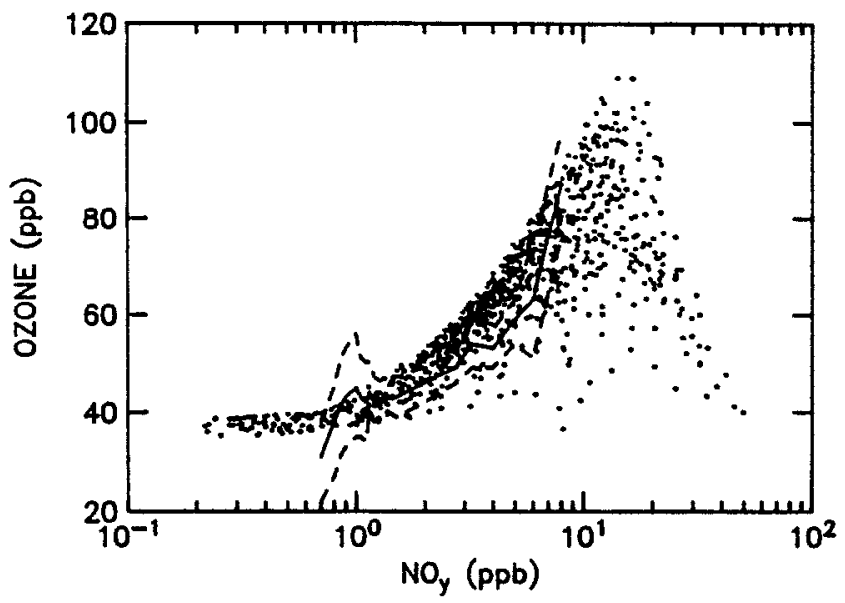

Fig. 5. $\mathrm{O}_{3}$ vs $\mathrm{NO}_{y}$ concentrations (in ppb) at 6 p.m. predicted by a $20 \times 20 \mathrm{~km}$ Eulerian grid model for Indiana, Ohio and western Pennsylvania. The lines show the average and standard deviation of observed $\mathrm{O}_{3}$ concentrations as a function of observed $\mathrm{NO}_{y}$ at Niwot Ridge, Colorado. From Sillman et al. [13] with Niwot Ridge data from Fahey et al. [15].

alkyl nitrates, etc.). $\mathrm{NO}_{y}$ may be used as a surrogate for total $\mathrm{NO}_{x}$ emissions, since all $\mathrm{NO}_{y}$ species were originally emitted as $\mathrm{NO}_{x}$. Model calculations (Figure 5) predict a strong correlation between $\mathrm{O}_{3}$ and $\mathrm{NO}_{y}$ in rural locations. A correlation between $\mathrm{O}_{3}$ and $\mathrm{NO}_{y}$ has been observed at a rural site in Colorado [15] which corresponds to model predictions. A similar correlation between $\mathrm{O}_{3}$ and $\mathrm{NO}_{y}$ has recently been observed at rural eastern locations $[12,14]$.

Based on the above analysis, we suggest that analyses based on current photochemical mechanisms will all predict a strong relation between $\mathrm{NO}_{x}$ emissions and background rural $\mathrm{O}_{3}$. In contrast with the urban situation, analyses for background rural $\mathrm{O}_{3}$ are less likely to be sensitive to model assumptions (emission rates, wind fields, etc.). We emphasize that this conclusion does not apply to rural locations influenced by direct urban plumes (e.g. southern Connecticut, Lake Michigan shoreline), but only to the 0.08 to $0.10 \mathrm{ppm}$ 'ozone soup' that blankets the eastern U.S. during regional stagnation events.

\section{The $\mathrm{O}_{3}$ Exceedence of August 2, 1988}

Violations of air quality standards were recorded on August 2, 1988 at three locations in southeastern Michigan: Osborn High School (0.137 ppm), in northeast Detroit; New Haven $(0.144 \mathrm{ppm}), 60 \mathrm{~km}$ northeast of downtown Detroit; and Port Huron $(0.127 \mathrm{ppm}), 90 \mathrm{~km}$ northeast of downtown Detroit. At all sites the exceedence was short-lived and was followed by a sharp drop in $\mathrm{O}_{3}$. Maximum $\mathrm{O}_{3}$ occurred from 1 to 2 pm EST in Detroit, 2 to 3 at New Haven and at 3 to 4 Port Huron, suggesting that ozone-laden air progressed downwind from Detroit. Although the 5 other monitoring sites in southeast Michigan did not register an exceedence, $\mathrm{O}_{3}$ 
levels of $0.100 \mathrm{ppm}$ or higher were recorded everywhere except at Saline $(0.085$ ppm maximum) and Ann Arbor (0.08 ppm).

In addition, violations of air quality standards also occurred at locations in Illinois, Wisconsin, Indiana, Ohio and Kentucky on both August 1 and August 2. Although most available observations represent urban sites, there are indications that $\mathrm{O}_{3}$ was higher than normal in rural locations as well. Nearly all sites in the 6-state region recorded $\mathrm{O}_{3}$ values of $>0.070 \mathrm{ppm}$, considerably higher than clean-air $\mathrm{O}_{3}$ [16].

The meteorology on August 1 and 2 was marked by southwesterly air flow throughout the midwest with temperatures in excess of $35^{\circ} \mathrm{C}\left(95^{\circ} \mathrm{F}\right)$. The afternoon mixed layer height was determined to be 1830 meters, based on rawinsonde observations at Flint, MI. Back-trajectory analysis [17] indicated that air located in southeastern Michigan on August 2 had been in Missouri July 30 and in northern Texas on July 29. Surface winds in the Detroit were light (1-2 $\left.\mathrm{m} \mathrm{sec}^{-1}\right)$ during the morning of August 2. Wind speeds increased to $4 \mathrm{~m} \mathrm{~s}^{-1}$ after 1 p.m. [18] possibly contributing to lower $\mathrm{O}_{3}$ concentrations in the late afternoon.

\section{Simulation Methods}

Regional-scale simulations were performed using the Plumes Model, which is described in detail elsewhere [19]. Because the Plumes Model represents an unfamiliar approach to the task of air quality modeling a brief summary will be presented here. In comparison with other models, the Plumes Model uses an extremely coarse horizontal grid, $400 \times 480 \mathrm{~km}$. Ordinarilly, use of such a large grid would lead to errors in the representation of photochemical processes, since no distinction is made between urban, suburban and rural locations. To avoid this, the Plumes Model uses a sub-grid structure within each $400 \times 480 \mathrm{~km}$ horizontal grid box. The sub-grid structure, illustrated in Figure 6, divides each grid box into regions representing (a) the evolution of an urban plume, including both the urban center and downwind diffusion; (b) the evolution of a power plant plume from source to diffuse downwind plume; and (c) the evolution of the remainder of the rural air mass. The plume sub-grid boxes export $\mathrm{O}_{3}, \mathrm{NO}_{x}$ and VOC into the rural subgrid box, as happens in the real-world situation.

The Plumes Model has been extensively tested in comparison with an equivalent model with a $20 \times 20 \mathrm{~km}$ grid. Results [19] show that Plumes Model calculations for average $\mathrm{O}_{3}, \mathrm{NO}_{x}, \mathrm{PAN}, \mathrm{HNO}_{3}$ and $\mathrm{OH}$ agree with $20 \times 20 \mathrm{~km}$ grid calculations to within a few percent. Limited tests have also been made against rural $\mathrm{O}_{3}$ observations. In contrast, standard grid models with resolution of $80 \times 80 \mathrm{~km}$ or larger may make significant errors in comparison with a $20 \times 20 \mathrm{~km}$ model, overestimating $\mathrm{O}_{3}$ and other secondary species and underestimating $\mathrm{NO}_{x}$. Use of the Plumes Model involves some disadvantages in that (a) the model accurately provides region-wide average concentrations only, and (b) variations in rural $\mathrm{O}_{3}$ concentrations on a spatial scale smaller than $400 \times 480 \mathrm{~km}$ is represented crudely. 


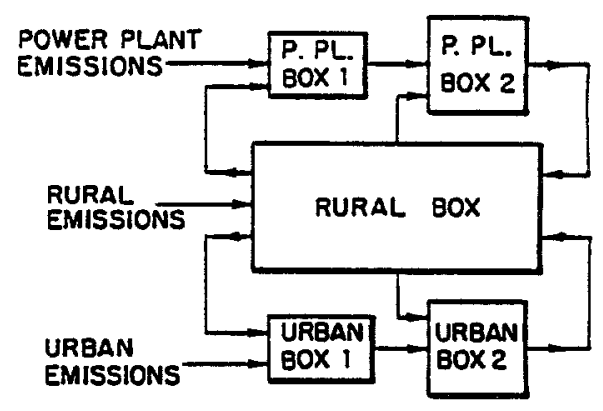

Fig. 6. Diagram of the Plumes Model subgrid structure, with boxes representing evolving urban and power plant plumes and rural area.

However it offers a large savings in computation time, and can be used more easily to explore alternative scenarios or processes that occur on a large spatial scale.

For urban applications the Plumes Model has been combined with a $5 \times 5 \mathrm{~km}$ urban grid model (UGM), the latter providing an urban 'window' within the Plumes Model structure to represent local processes in a specific urban region. In the combined model the rural subsection of the Plumes Model is used to provide boundary conditions for the UGM. This combined approach is successful only when species concentrations upwind of the UGM can be represented by the $400 \times 480$ $\mathrm{km}$ rural average concentrations calculated by the Plumes Model. The size of the UGM must be chosen to avoid the possibility of ignoring transport from an adjacent urban area. Both the Plumes Model and the UGM use the photochemical mechanism of Lurmann et al. (complete form) [20] with photolysis rates from Logan et al. [21]. Horizontal advection is by second-order moments [22] in the Plumes Model and by the method of Smolarkiewicz [23] in the UGM. The models include two vertical layers, a time-varying mixed layer and an entrainment layer, with the diurnal variation of the mixed layer derived from van Ulden and Holtslag [24]. Deposition velocities are as follows: $\mathrm{HNO}_{3}, 2.5 \mathrm{~cm} \mathrm{~s}^{-1}, \mathrm{O}_{3}$ and $\mathrm{NO}_{2}, 0.6 \mathrm{~cm} \mathrm{~s}{ }^{-1}$; $\mathrm{NO}, 0.1 \mathrm{~cm}$ $\mathrm{s}^{-1} ; \mathrm{H}_{2} \mathrm{O}_{2}$ and $\mathrm{ROOH}, 1.0 \mathrm{~cm} \mathrm{~s}^{-1}$; and PAN, $0.25 \mathrm{~cm} \mathrm{~s}^{-1}$. Initial and boundary conditions are $40 \mathrm{ppb} \mathrm{O}_{3}, 5 \mathrm{ppbC}$ VOC and $0.2 \mathrm{ppb} \mathrm{NO}_{x}$. Anthropogenic emissions are from the NAPAP Version 5.2 inventory [25]. Biogenic emissions of isoprene were derived from Lamb et al. [26] based on land used data from matthews [27]. Other biogenic species were not included.

In order to represent the Detroit $\mathrm{O}_{3}$ excursion of August 2, the combined model was exercised for a 4-day period (July 30-August 2). The Plumes Model was used to represent photochemical evolution for a region bounded roughly by Detroit, Atlanta, GA, Dallas, and Omaha, NB (Figure 7). The UGM grid covered the corridor from Detroit to Port Huron. Both model domains were chosen based on observed wind fields during the period. Regional transport in the Plumes Model was calculated based on average wind speeds between 0 and $1500 \mathrm{~m}$. Transport in the UGM was based on surface winds, which were considerably lighter than winds 


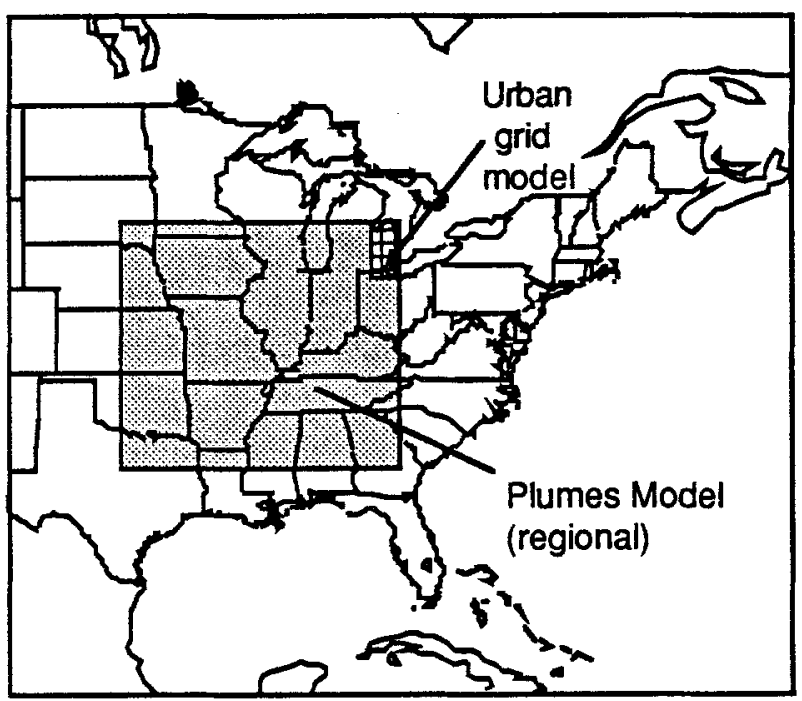

Fig. 7. Domain for the combined urban/regional simulation for July 30-August 2, 1988.

aloft. Isoprene emissions within the Detroit-Port Huron corridor were included, assuming $20 \%$ forest cover (the same percentage used for rural lower Michigan). The resulting emission rate for isoprene, adjusted for the abnormally warm temperatures of the period, was $3.15 \times 10^{11}$ molecules $\mathrm{cm}^{2} \mathrm{sec}^{-1}$ (daytime). At this rate, isoprene would account for $16 \%$ of daytime VOC emissions in the DetroitPort Huron corridor ( $4 \%$ in the city of Detroit), and more than $50 \%$ of daytime VOC emissions over the regional model domain.

\section{Results}

The simulation predicted rural $\mathrm{O}_{3}$ concentrations of $0.075 \mathrm{ppm}$ in Michigan on August 2, with concentrations of $0.085-0.090 \mathrm{ppm}$ in locations affected by diffuse urban or power plant plumes. Predicted rural $\mathrm{O}_{3}$ compared well with observations at Saline $(0.080$ to $0.085 \mathrm{ppm})$ and Ann Arbor (0.075-0.080 ppm). Predicted $\mathrm{O}_{3}$ also shows good agreement with observations at twelve rural and small urban locations throughout the midwest (Table 1). The model significantly underestimates $\mathrm{O}_{3}$ at four rural sites (Madison, WI, Moline, IL, Decatur, IL and Paducah, KY), possibly due to the influence of local emission sources. The model overestimates $\mathrm{O}_{3}$ at one site (Mammoth Cave, KY). The overall comparison suggests that the model accurately characterizes $\mathrm{O}_{3}$ concentrations throughout the air mass, though it may underestimate $\mathrm{O}_{3}$ in northwestern Illinois and Wisconsin.

Simulated urban $\mathrm{O}_{3}$ (Table 1 and Figure 8 ) showed generally good agreement with observed values at sites throughout the Detroit area but had some major discrepancies. Predicted peak $\mathrm{O}_{3}$ for August $2(0.159 \mathrm{ppm})$ is significantly higher than the observed peak at New Haven $(0.144 \mathrm{ppm})$. As shown in Figure 8 the 
TABLE I

Simulated vs observed peak $\mathrm{O}_{3}$ concentrations (ppm) for Detroit and rural Midwestern sites

\begin{tabular}{|c|c|c|c|c|}
\hline & \multicolumn{2}{|l|}{ August 1} & \multicolumn{2}{|l|}{ August 2} \\
\hline & Simulated & Observed & Simulated & Observed \\
\hline \multicolumn{5}{|l|}{ Rural } \\
\hline Ann ARbor, MI & 0.072 & 0.080 & 0.076 & 0.080 \\
\hline Lima, $\mathrm{OH}$ & 0.072 & 0.066 & 0.076 & 0.066 \\
\hline Columbus, $\mathrm{OH}$ & 0.073 & 0.071 & 0.075 & 0.078 \\
\hline Madison, WI & 0.061 & 0.073 & 0.060 & 0.072 \\
\hline Moline, IL & 0.061 & 0.077 & 0.060 & 0.074 \\
\hline Quincy, IL & 0.058 & 0.061 & 0.057 & 0.056 \\
\hline Decatur, IL & 0.058 & 0.073 & 0.057 & 0.081 \\
\hline Terre Haute, IN & 0.065 & 0.062 & 0.066 & 0.066 \\
\hline Paducah, KY & 0.055 & 0.069 & 0.054 & 0.073 \\
\hline Mammoth Cave, KY & 0.069 & 0.053 & 0.068 & 0.058 \\
\hline Shepherdsville, KY & 0.069 & 0.088 & 0.068 & 0074 \\
\hline Livingston, $\mathrm{KY}$ & 0.074 & 0.080 & $0 ; 073$ & 0.081 \\
\hline \multicolumn{5}{|l|}{ Urban } \\
\hline Detroit, MI & 0.095 & 0.110 & 0.128 & 0.137 \\
\hline Warren, MI & 0.102 & 0.102 & 0.129 & 0.111 \\
\hline Southfield, MI & 0.090 & 0.098 & 0.108 & 0.102 \\
\hline New Haven, MI & 0.113 & 0.109 & 0.159 & 0.144 \\
\hline Port Huron, MI & 0.114 & 0.126 & 0.149 & 0.127 \\
\hline
\end{tabular}

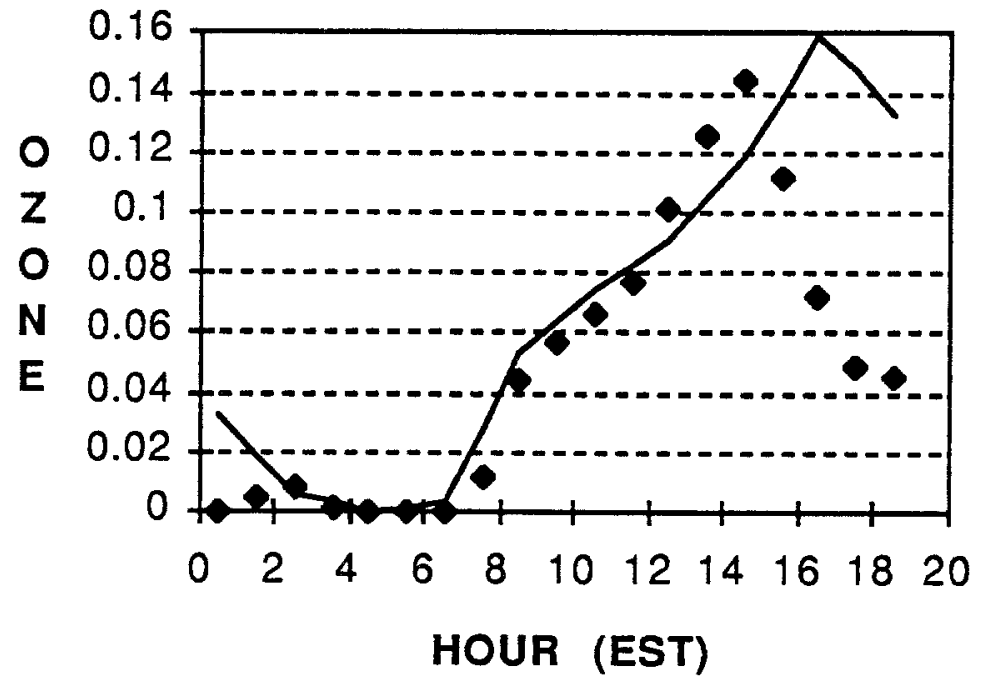

Fig. 8. Simulated $\mathrm{O}_{3}$ at New Haven, Michigan, (line) on August 2, 1988, compared with observations (dots). 
major discrepancy occurs in late afternoon, when simulated $\mathrm{O}_{3}$ reaches its peak and observed $\mathrm{O}_{3}$ drops sharply. This pattern suggests that the error may be associated with inaccuracies in the wind fields used in the model. The predicted geographical variation also is in close agreement with observations, with peak $\mathrm{O}_{3}$ occurring at Port Huron on August 1 and New Heaven on August 2.

Concentrations of $\mathrm{NO}_{x}$ and VOC on August 2 are not available, but limited comparisons can be made with observations on other days. Kelly et al. [28] report average $\mathrm{VOC} / \mathrm{NO}_{x}$ ratios of 4.8:1 based on 6-9 a.m. observations on 90 summer days in 1981, with slightly higher ratios (5.6:1) on days with high $\mathrm{O}_{3}$. The predicted VOC/NO $\mathrm{Natio}_{x}$ (4.5:1 on August 1, 6.5:1 on August 2) is consistent with these observations, although higher ratios (7:1 and 9:1) are predicted for $10 \mathrm{~km}$ north of Detroit. Simulated rural concentrations of VOC $(\sim 20 \mathrm{ppbC}$ at noon), isoprene $(0.3 \mathrm{ppb})$ and $\mathrm{NO}_{x}(0.5 \mathrm{ppb})$ are also broadly consistent with observations at rural sites in eastern North America [14, 29, 30].

One important aspect of the August 1-22 episode has not been represented: the unusually high $\mathrm{O}_{3}$ concentrations in the Lake Michigan airshed. During August 1-2 high $\mathrm{O}_{3}(>.15 \mathrm{ppm})$ was observed at numerous sites bordering Lake Michigan: Kenosha, Racine and Manitowoc, WI, and Muskegon, MI. A modification of the UGM is currently being planned to represent the complicated circulation pattern in the vicinity of Lake Michigan. Since surface winds throughout the Lake Michigan airshed were from the south and southwest on both August 1 and August 2, these processes were unlikely to affect the Detroit area.

\section{Impact of Regional Emissions on $\mathrm{O}_{3}$ in Detroit}

The combined urban/regional model was exercised for a variety of changed VOC and $\mathrm{NO}_{x}$ emission scenarios. The specific goal of the emission scenarios was to identify the potential impact of emissions from distant upwind sources on peak $\mathrm{O}_{3}$ in the Detroit-Port Huron corridor. We are especially interested to identify differences between abatement strategies from an analysis limited to emissions in the Detroit-Port Huron corridor, and strategies derived based on a regional-scale analysis. Consequently the model exercises included scenarios with changed emissions in the Detroit-Port Huron corridor only, and scenarios with changed emissions throughout the area covered by the regional grid.

The effect of reduced VOC emissions is shown in Figure 9. Reduced VOC emissions are predicted to lower peak $\mathrm{O}_{3}$ within the Detroit-Port Huron corridor. However VOC reductions at upwind locations are predicted to have virtually no impact on $\mathrm{O}_{3}$ in the Detroit area. As shown in Figure 9, the difference between the urbanonly and regional emission reduction scenarios is less than $0.005 \mathrm{ppm}$, even when region-wide reductions amount to $60 \%$. Reduced VOC emissions also have no impact on Saline, a rural site upwind of Detroit with $\mathrm{O}_{3}$ equivalent to the rural background. Regional VOC reductions have little impact because background rural $\mathrm{O}_{3}$ is sensitive to $\mathrm{NO}_{x}$ rather than to $\mathrm{VOC}$ throughout the model domain. Direct transport of 


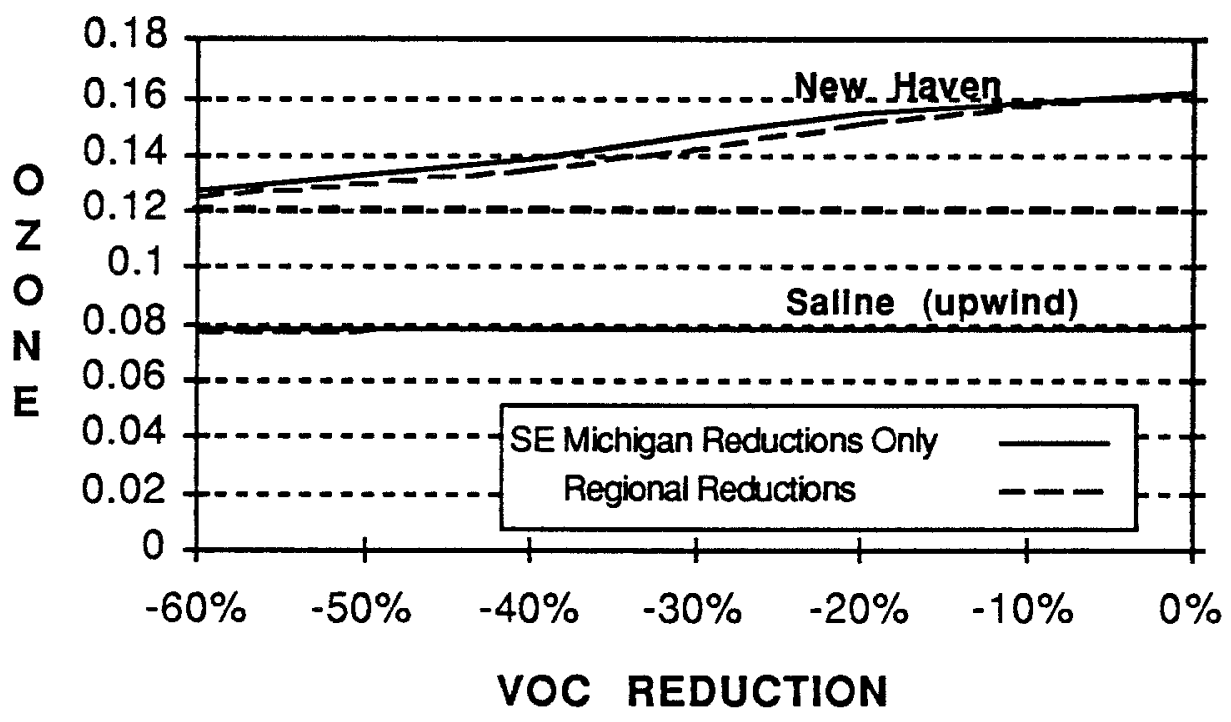

Fig. 9. Predicted peak $\mathrm{O}_{3}$ (ppm) with reduced VOC emissions in southeast Michigan (solid lines) and with reduced VOC emissions throughout the model domain (dashed lines).

VOC into the Detroit area is insignificant in comparison to local emissions for the meteorology of this particular event.

Reduced $\mathrm{NO}_{x}$ emissions also cause a drop in Detroit $\mathrm{O}_{3}$, but in contrast to VOC, $\mathrm{NO}_{x}$ has a larger impact on regional transport. As shown in Figure 10, $\mathrm{NO}_{x}$ emissions have a substantial impact on rural $\mathrm{O}_{3}$ concentrations upwind of Detroit. $\mathrm{O}_{3}$ at New Haven drops partly in response to local $\mathrm{NO}_{x}$ reductions and partly due to regional $\mathrm{NO}_{x}$ reductions upwind of Detroit. $\mathrm{NO}_{x}$ emissions from as far away as Illinois appear to have an impact on Detroit $\mathrm{O}_{3}$.

The relationship between $\mathrm{NO}_{x}$ emissions and regional transport shown here is consistent with the theoretical analysis presented above and in agreement with previous studies $[11,13]$ linking $\mathrm{O}_{3}$ production in rural areas to $\mathrm{NO}_{x}$ rather than to anthropogenic VOC. The impact of upwind $\mathrm{NO}_{x}$ reductions (roughly equal in size to the impact of reduced local $\mathrm{NO}_{x}$ ) occurs because upwind $\mathrm{NO}_{x}$ reductions reduce background rural $\mathrm{O}_{3}$, which in turn reduces transport of $\mathrm{O}_{3}$ into the Detroit area.

Although it is dangerous to make policy choices based on results of a single model for a single event, the results shown in Figures 9 and 10 have implications pertaining to the choice between $\mathrm{VOC}$ and $\mathrm{NO}_{x}$ controls that are likely to be repeated in subsequent analyses. First, VOC controls appear more effective than $\mathrm{NO}_{x}$ controls if only relatively modest $(20 \%)$ emission reductions are made. $\mathrm{NO}_{x}$ controls appear to be comparatively more effective relative to VOC controls as the percent reduction is increased, so that if a $50 \%$ reduction is contemplated, $\mathrm{NO}_{x}$ controls appear more effective than VOC controls. This difference between the $\mathrm{NO}_{x} / \mathrm{VOC}$ choice with a $20 \%$ reduction, in contrast to the choice with a $50 \%$ reduction, is consistent 


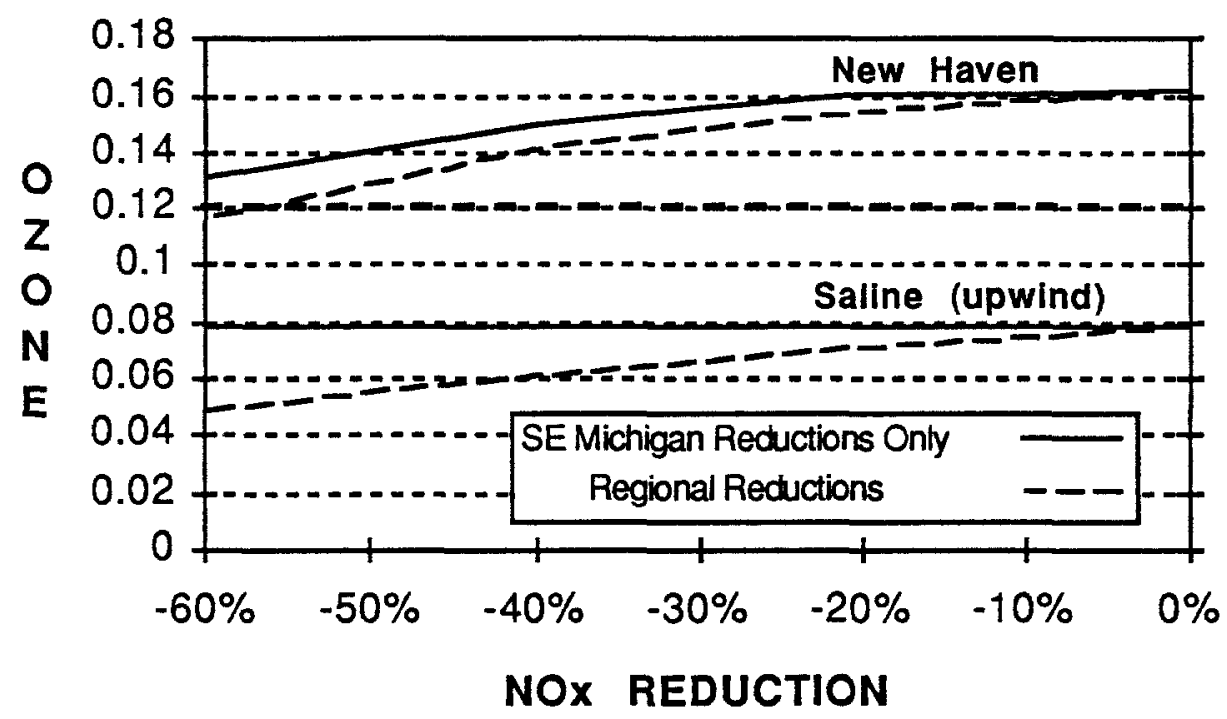

Fig. 10. Predicted peak $\mathrm{O}_{3}(\mathrm{ppm})$ with reduced $\mathrm{NO}_{x}$ emissions in southeast Michigan (solid lines) and with reduced $\mathrm{NO}_{x}$ emissions throughout the model domain (dashed lines).

with the view of photochemical processes that emerged from Possiel [10]. $\mathrm{NO}_{x}$ controls appear to be more effective in reducing moderate $\mathrm{O}_{3}$, while VOC controls appear more effective in reducing severe $\mathrm{O}_{3}$. Second, the inclusion of a regional scale analysis makes the option of $\mathrm{NO}_{x}$ controls appear more attractivce than it would if an urban-only analysis were used. A $50 \% \mathrm{NO}_{x}$ reduction would appear equivalent to a $50 \%$ VOC reduction, if the analysis were limited to the Detroit area, but the inclusion of region-wide reductions makes a $50 \% \mathrm{NO}_{x}$ reduction appear significantly more effective than a $50 \%$ VOC reduction.

\section{Conclusion}

A regional-scale simulation has been used to investigate control strategies for $\mathrm{O}_{3}$ in the Detroit metropolitan area. The model combined a detailed urban grid for Detroit with a regional simulation that accounted for precursor emissions from as far away as Texas. Simulated $\mathrm{O}_{3}$ agrees with observed concentrations at locations throughout the Detroit area and at rural sites throughout the midwest. A more extensive comparison between model results and observed urban and rural VOC and $\mathrm{NO}_{x}$ concentrations is needed in order to insure that the simulated processes correspond to atmospheric conditions.

The focus of the exercise has been to contrast the results of a regional-scale analysis for $\mathrm{O}_{3}$ with an analysis limited to a single metropolitan area. VOC controls have little regional impact, but $\mathrm{NO}_{x}$ controls have a significant impact on regional transport of $\mathrm{O}_{3}$. Consequently analyses that do not include regional transport may underestimate the impact of $\mathrm{NO}_{x}$. 
If the results presented here are correct, they would seriously stress existing policymaking procedures. Under current practice in the U.S. emission controls are applied on a state-by-state basis except in locations where major metropolitan areas lie close to state boundaries (i.e. the northeast corridor). The results presented here suggest that regional transport has a significant impact even in a location (Detroit) where upwind sources lie hundreds of miles away. The results also suggest that the best VOC-reduction strategy may have no impact on regional transport. To express this at its (exaggerated) worst, the results suggest that individual metropolitan areas will benefit by reducing their own VOC emissions, and by having their upwind neighbors reduce $\mathrm{NO}_{x}$ emissions. New regulatory mechanisms may be needed to cope with this difficult situation.

\section{References}

[1] Samson, P. J. and Ragland, K.: 1977, 'Ozone and Visibility Reduction in the Midwest: Evidence for Large-Scale Transport. J. Appl. Meteor. 16, 1101.

[2] Hov, O., Hesstvedt, E., and Isaksen, I. S. A.: 1978, 'Long-Range Transport of Tropospheric Ozone', Nature 273, 341.

[3] Wolff, G. T. and Lioy, P. J.: 1980, 'Development of an Ozone River Associated with Synoptic Scale Episodes in the Eastern United States', Environ. Sci. Technol. 14, 1257.

[4] Logan, J. A.: 1989, 'Ozone in Rural Areas of the United States', J, Geophys. Res. 94, 8511.

[5] Walker, H. M.: 1985, 'Ten-year Ozone Trends in California and Texas', J. Air Pollut. Control Assoc. 35, 903.

[6] Clarke, J. F. and Ching, J. K. S.: 1983, 'Aircraft Observations of Regional Transport of Ozone in the Northeastern United States', Atmos. Environ. 17, 1703.

[7] Samson, P. J. and Shi, B.: 1988, 'A Meteorological Investigation of High Ozone Values in American Cities', Prepared for U.S. Congress, Office of Technology Assessment, Washington, D. C., August, 1988.

[8] Seinfeld, J. H.: 1989, 'Urban Air Pollution: State of the Science', Science 243, 745.

[9] Scheffe, R.: 1990, The Five Cities Study, Presented at the Symposium on the Role and Importance of Nitrogen Oxides Emission Controls in Ozone Attainment Strategies for Eastern North America. Northeast States for Coordinated Air Use Management (NESCAUM), Boston, MA, May 30-June $1,1990$.

[10] Possiel, N.: 1990, The Role of Nitrogen Oxide Emissions in Oxidant Production as Predicted by the Regional Oxidant Model (ROM), Presented at the Symposium on the Role and Importance of Nitrogen Oxides Emission Controls in Ozone Attainment Strategies for Eastern North America. Northeast States for Coordinated Air Use Management (NESCAUM), Boston, MA, May 30-June $1,1990$.

[11] Milford, J., Russell, A. G., and McRae, G. J.: 1989, 'A New Approach to Photochemical Pollution Control: Implications of Spatial Patterns in Pollutant Responses to Reductions in Nitrogen Oxides and Reactive Organic Gas Emissions, Environ. Sci. Tech. 23, 1290.

[12] Trainer, M., Williams, E. J., Parrish, D. D., Buhr, M. P., Allwine, E. J., Westberg, H. H., Fehsenfeld, F. C., and Liu, S. C.: 1987, 'Models and Observations of the Impact of Natural Hydrocarbons on Rural Ozone', Nature 329, 705.

[13] Sillman, S., Logan, J. A., and Wofsy, S. C.: 1990, 'The Sensitivity of Ozone to Nitrogen Oxides and Hydrocarbons in Regional Ozone Episodes, J. Geophys. Res. 95, 1837.

[14] Demerjian, K.: 1990, 'Spatial and Temporal Patterns in Ambient Concentrations of Oxidants, Reactive Organic Compounds and Nitrogenous Compounds', Presented at the Symposium on the Role and Importance of Nitrogen Oxides Emission Controls in Ozone Attainment Strategies for Eastern North America. Northeast States for Coordinated Air Use Management (NESCAUM), Boston, MA, May 30-June 1, 1990. 
[15] Fahey, D. W., Hubler, G., Parrish, D. D., Williams, E. J., Norton, R. B., Ridley, B. A., Singh, H. B., Liu, S. C., and Fehsenfeld, F. C.: 1986, Reactive nitrogen species in the troposphere: Measurements of $\mathrm{NO}, \mathrm{NO}_{2}, \mathrm{HNO}_{3}$, particulate nitrate, peroxyacetylnitrate (PAN), $\mathrm{O}_{3}$ and total reactive odd nitrogen $\left(\mathrm{NO}_{p}\right)$ at Niwot Ridge, Cologado, J. Geophys. Res. 91, 9781.

[16] Michigan Department of Natural Resources: 1988, ozone monitoring sites.

[17] Heffter, J. L.: 1981, 'Air Resources Laboratories Atmosopheric Transport and Dispersion Model (ARL-ATAD), NOAA Tech. Memo. ERL-ARL-81, Air Resources Laboratories, Silver Spring, MD, $17 \mathrm{p}$.

[18] Foltman, R.: 1988, Detroit Edison Company, based in Detroit Edison mesoscale wind measurements network.

[19] Sillman, S., Logan, J. A., and Wofsy, S. C.: 1990, 'A Regional-Scale Model for Ozone in the United States with a Sub-Grid Representation of Urban and Power Plant Plumes', J. Geoph. Res. 95, 5731 .

[20] Lurmann, F. W., Lloyd, A. C., and Atkinson, R.: 1986, 'A Chemical Mechanism for Use in LongRange Transport/Acid Deposition Computer Modeling', J. Geophys. Res. 91, 10905.

[21] Logan, J. A., Prather, M. J., Wofsy, S. C., and McElroy, M. B.: 1981, 'Tropospheric Chemistry: A Global Perspective', J. Geophys. Res. 86, 7210.

[22] Prather, M. J.: 1986, 'Numerical Advection by Conservation of Second-Order Moments', J. Geophys. Res. 91, 6671.

[23] Smolarkiewicz, P. K.: 1983, 'A Simple Positive Definite Advection Scheme with Small Implicit Diffusion', Mon. Wea. Rev. 11, 479.

[24] Ulden, A. P. van, and Holtslag, A. A. M.: 1985, 'Estimation of Atmospheric Boundary-Layer Parameters for Diffusion Applications', J. Climate Apppl. Meteor. 24, 1196.

[25] U.S. Environment Protection Agency: 1986, 'Development of the 1980 NAPAP emissions inventory', EPA-600/7-86-057a, Environmental Protection Agency, Research Triangle Park, NC.

[26] Lamb, B., Westberg, H., Allwine, G., and Quarles, T.: 1985, 'Biogenic Hydrocarbon Emissions from Deciduous and Coniferous Trees in the United States', J. Geophys. Res. 90, 2380.

[27] Matthews, E.: 1983, 'Global Vegetation and Land Use: New High-Resolution Data Bases for Climate Studies', J. Climate Appl. Meteorol. 22, 474.

[28] Kelly, N. A., Ferman, M. A., and Wolff, G. T.: 1986, 'The Chemical and Meteorological Conditions Associated with High and Low Ozone Concentrations in Southeastern Michigan and Nearby Areas of Ontario', J. Air Pollut. Control Assoc. 36, 150.

[29] Arnts, R. A. and Meeks, S. A.: 1981, 'Biogenic Hydrocarbon Contribution to Ambient Air in Selected Areas', Atmos. Environ. 15, 1643.

[30] Sexton, KJ. and Westberg, H.: 1984, 'Non-Methane Hydrocarbon Composition of Urban and Rural Atmospheres', Atmos. Environ. 18, 1125. 